\title{
Moral transformation in the Johannine writings
}

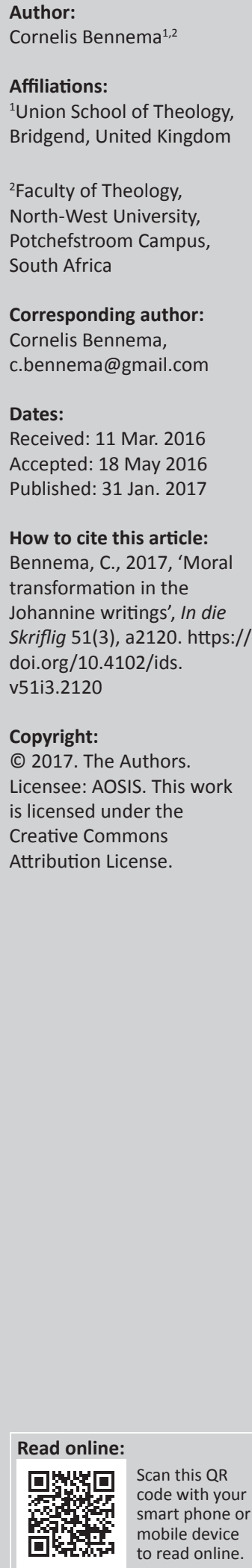

\begin{abstract}
Johannine ethics is a problematic area for scholarship but recently there has been a breakthrough. In this new era of Johannine ethics, the present article examines the concept of moral transformation. The argument is that the Johannine writings present a moral narrative world where a moral God saves immoral people by bringing them into his moral world. When people live in God's moral world their character and conduct are shaped in accordance with the moral beliefs, values and norms of the divine reality. In order to model and promote the envisaged morality amongst his readers, John presents various characters, whose characteristics and behaviour might be either emulated or avoided.
\end{abstract}

This article is dedicated to Jan van der Watt for his exemplary scholarship and friendship. The topic of this article is the concept of moral transformation in the Johannine writings. ${ }^{1}$ Though the subject of Johannine ethics has only existed at the periphery of scholarship since the 1970s, Jan van der Watt has doggedly pursued the topic since 1999 (the List of References only contains a selection). The crucial breakthrough came in 2012 with the publication of a collection of essays (Van der Watt \& Zimmermann 2012). This landmark study provided a doorway for scholars to explore afresh the ethical horizons of the Johannine writings. Building on Van der Watt's pioneering work, I will argue that the Johannine writings present a moral narrative world (section 1), and envisage people's moral transformation (section 2). The first section is a preparation for the more substantial second section, the main focus of the study.

As a working definition, I use the term moral transformation to refer to the shaping of, or change in a person's character and conduct when they understand, embrace and live out the beliefs, values and norms of God's world. As a child of God, the believer has been transferred from the immoral world 'below' to the moral world 'above' and must now think and live in line with this new environment. This socio-religious relocation initiates a process of moral transformation. However, it is only conceivable to speak of moral transformation in the Johannine writings if John presents a moral God and if his writings have a moral dimension, lest we import a foreign category. I will therefore first show that the Johannine writings have a moral purpose and contain a moral narrative.

\section{A moral narrative world}

When viewed against Graeco-Roman virtue ethics, I contend that the Johannine corpus has a strong

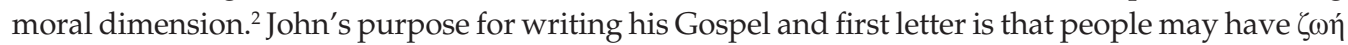
[life] through believing in Jesus (20:31; 1 Jn 5:13). I suggest that this purpose is not only soteriological but also ethical in nature, firstly because 'the good life' is a moral goal and secondly, John presents 'belief in Jesus' as the singular moral 'work' for obtaining this moral goal. Discourse on virtue

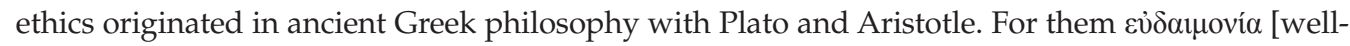
being, happiness] is the supreme good that people should pursue for its own sake and not for the sake of anything else; it describes that state achieved by the person who lives the proper human life (e.g. Aristotle Nicomachean Ethics I.2-4). In the Johannine literature, $\zeta \omega \eta$ is the closest equivalent to this highest good. John indicates two kinds of life, namely $\psi v 0 \eta$ as the transient, finite human life that can be laid down $(12: 25 ; 13: 37 ; 15: 13)$; and $\zeta \omega \eta$ that denotes the divine, everlasting life that the Father and Son share and that defines them $(1: 4 ; 5: 21,26 ; 6: 57 ; 14: 6)$. In the Johannine scheme of things, people do not (naturally) know God - not in the sense that it saves them - and hence the

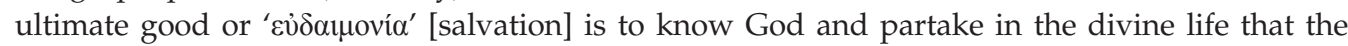

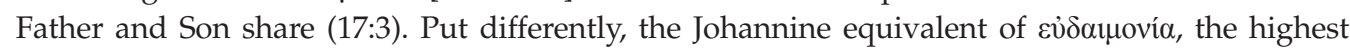

1.The similarity in language, style and thought of the Gospel and the epistles warrants an examination of both writings, even as common authorship is debated. For the sake of convenience, I will refer to the author(s) as 'John'.

2.Rather than claiming that John intentionally drew on Graeco-Roman morality, I merely suggest that virtue ethics is a useful heuristic framework for understanding Johannine ethics.

3.Bible texts with only reference to the chapter and verse come from the Gospel of John. 
good for people, is to be in a relationship with the Father and

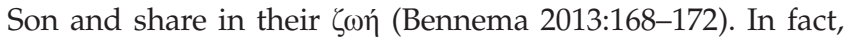
$\zeta \omega \eta$ is the Johannine shorthand for salvation. The Prologue introduces Jesus as 'in him was $\zeta \omega \eta^{\prime}$ ' (1:4) and the rest of the Gospel spells out how there is $\zeta \omega \eta$ in Jesus and how he makes it available to people. If $\zeta \omega \eta$ is the highest moral good people can achieve when they enter into a relationship with the Father and Son (since it is only there that $\zeta \omega \eta$ is available), then the entire Johannine narrative is a moral one.

If $\zeta \omega \eta$ is a moral objective, the means for obtaining it is 'practising' a particular Johannine virtue $-\pi \imath \sigma \tau \varepsilon v ́ \varepsilon ı v$ [to

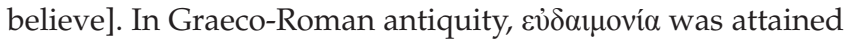
by practising certain virtues during one's life (Aristotle NE I.7). For John, $\pi 1 \sigma \tau \varepsilon v i \varepsilon ı v$ is the singular virtue essential for achieving

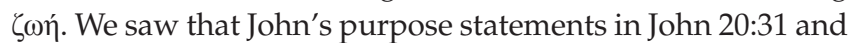
1 John 5:13 explicitly state that the means for obtaining

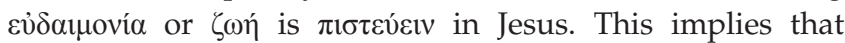
$\pi ı \tau \varepsilon v i \varepsilon v$ has a moral dimension. We see this confirmed in

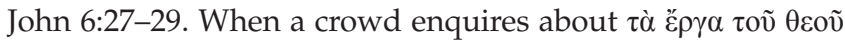
following Jesus' exhortation 'to work' for food that leads to $\zeta \omega \eta$, Jesus explains that the singular čprov God requires from them is $\pi \imath \tau \tau \varepsilon v \varepsilon \varepsilon v$ in Jesus. ${ }^{4}$ Believing is a moral act in that it acknowledges the true identity and work of God and Jesus, and their relationship. In other words, $\pi \iota \sigma \tau \varepsilon v \varepsilon \varepsilon v$ in Jesus is not only a moral act because it is the sole means by which people attain $\zeta \omega \eta$, the highest moral good, but also because, as the sole है prov God requires, it is the proper moral response that people should render to God (cf. Van der Watt 2011:433-435).

While the Johannine writings evidently depict God in soteriological terms, I suggest that they also present him as a moral God when one considers God's identity and the 'work' he is involved in. John's characterisation of God and Jesus as $\varphi \tilde{\omega} \varsigma$ [light] $(1: 4-5 ; 8: 12 ; 1$ Jn 1:5, 2:8) has a moral dimension when viewed against $\sigma \kappa o \tau i ́ \alpha$ [darkness], which characterises people and the devil. For John light is a moral good or quality because it enlightens people's dark minds

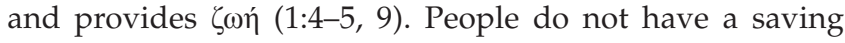
knowledge of God apart from the Logos-Light who enlightens people by revealing God $(1: 9,18 ; 8: 12 ; 12: 46$; cf. 1 Jn 5:20). The darkness that characterises the world and its people is inter alia a moral darkness because the dark world rejects the life-giving Light (1:4-11). People engage in morally dubious behaviour ( $\pi \rho \alpha ́ \tau \tau \varepsilon ı v ~ \varphi \alpha \tilde{\lambda} \lambda \alpha$ ) and have immoral inclinations - they have a strong aversion to the

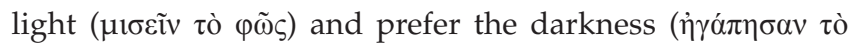

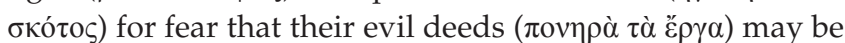
exposed (3:19-20; cf. 7:7). The ruler of the world, the devil, is also characterised in immoral terms such as 'the evil one'

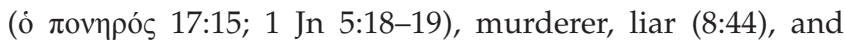
sinner (1 Jn 3:8; sin is morally wrong - $\alpha \delta$ iкía; 1 Jn 5:17). As such, people in the world are under the rule of 'the evil one', enslaved to $\sin (8: 34)$, children of the devil $(8: 44 ; 1$ Jn 3:8) and characterised by immoral behaviour (3:19-20; 7:7).

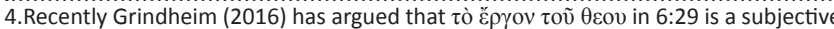
genitive, referring to the work that God does, rather than an objective genitive,
referring to the work that God expects from people. It is possible, however, that referring to the work that God expects from p
both aspects are in view (cf. Lincoln 2005:227).
In contrast to the devil and human beings, John characterises God and Jesus by various moral attributes or properties:

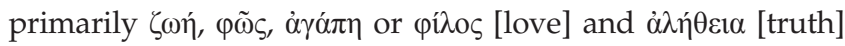
(see further in the section 'Moral values' below), but also

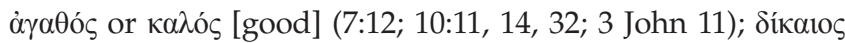
[righteous, just] (5:30; 17:25; 1 Jn 1:9; 2:1, 29; 3:7); 'sinless'

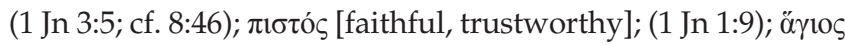
[holy] (6:69; 17:11); and óyvós [pure] (1 Jn 3:3). These moral qualities describe both the character or identity of God and Jesus as well as their behaviour. For example Jesus is regarded as being 'good' $(10: 11,14)$ and doing 'good' $(10: 32)$; Jesus is life $(1: 4 ; 14: 6)$ and gives life $(5: 21)$; Jesus is light $(1: 5,9 ; 8: 12)$ and gives light (1:5, 9; 1 Jn 2:8); Jesus acts justly and is just (5:30; 1 Jn $2: 1,29)$; Jesus is truth and testifies to the truth $(14: 6 ; 18: 37)$; God is love (1 Jn 4:8, 16) and acts in love (3:16; 5:20; 1 Jn 4:9-11,19). In short God and Jesus both embody and demonstrate these moral goods - they give and act out who they are. In addition, the work God is involved in has a moral dimension because God's ع̌prov, carried out by Jesus $(4: 34 ; 17: 4)$, is to deliver people from moral darkness $(3: 19-20 ; 5: 17 ; 9: 3-4)$ and give them $\zeta \omega \eta$, the chief moral benefit. God's moral work of saving people includes liberation, cleansing, sanctification and forgiveness (8:32; 15:3; 17:17, 19; 1 Jn 1:9; 2:1).

In conclusion, the Johannine literature presents a moral narrative world where two mutually exclusive moral realms and rulers are pitted against each other. ${ }^{5}$ Immoral categories such as lies, hate, sin, darkness and murder are related to the devil and his realm (including its people). Moral attributes or qualities such as life, light, love, truth, good, righteous, forgiveness, cleansing and sanctification are ascribed to God and Jesus and those who belong to him. The ultimate moral

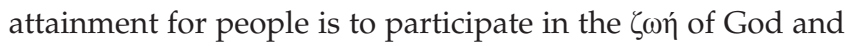
Jesus through the moral act of $\pi \imath \sigma \tau \varepsilon v i \varepsilon v$ in Jesus.

\section{Moral transformation}

Having shown that the Johannine writings present a moral narrative world, we can move to the idea of moral transformation, which occurs when people live in proximity to a moral God. A person's moral transformation starts with a new birth by the Spirit, a relocation from the dark, immoral world to the moral world of God (1:12-13; 3:3-5; 17:14, 16). This relocation occurs when people 'practise' the virtue of $\pi \imath \tau \tau \varepsilon v i \varepsilon v$ in Jesus as the singular moral 'work' God requires. This new birth involves a new identity (one becomes a child of God in his family; 1:12-13) and this new identity should lead to new behaviour. But how does such moral transformation come about? I suggest that one's moral transformation corresponds to the extent one is able to think and behave in line with the divine reality. A renewed mindset is characterised by the ability to understand and embrace the worldview from above, driven by the moral beliefs, values and norms of God and his world. Renewed behaviour is characterised by conduct that is in line with what Jesus taught and exemplified.

5.Cf. Bolyki (2003) who employs the theory of ethical conflicts in ancient dramas to show that the conflict in the Gospel of John is also ethical in nature and part of John's moral story. 


\section{Moral values}

If John presents God as a moral being, one must ask what values of God's character and world will shape the identity and behaviour of believers. Though by no means exhaustive, I focus on four moral values that characterise God in the Johannine writings: life, light, love and truth. When people enter into God's family, and consequently participate in the relationship that the Father and Son share, these moral values or attributes begin to shape their identity and behaviour.

\section{Life}

This value is expressed by the noun $\zeta \omega \eta$ [(divine) life] and its

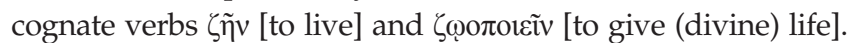
Z $\omega$ í is the everlasting, indestructible life that the Father and Son have in themselves and it even defines them $(1: 4 ; 5: 26 ; 11: 25-26$; 14:6; cf. 1 Jn 5:20). While people only possess $\psi v \chi \eta$, which is transient and destructible, entry into the divine family allows

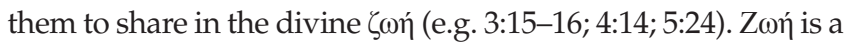
moral category because it represents the continual existence of

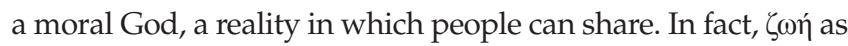
the ultimate moral good that people can achieve (20:31; $1 \mathrm{Jn}$ $5: 13)$, is the Johannine equivalent of $\varepsilon \dot{\delta} \delta \alpha \mu$ oví $\alpha$, the highest moral good for humans according to Graeco-Roman philosophy (see the section, 'A moral narrative world' above). ${ }^{6}$ In addition, as people partake in the shared life of the Father and Son, they become a derivative source of life for others $(7: 38 ; 17: 20){ }^{7}$

\section{Light}

This value is conveyed by the noun $\varphi \tilde{\omega} \varsigma$ [light] and its cognate verbs paíveıv [to shine] and $\varphi \omega \tau i \zeta \zeta \varepsilon ı$ [to give light]. Jesus is described as the life-giving light of the world $(1: 4-5,9 ; 8: 12$; 12:46) and God is also described as light (1 Jn 1:5). Light is a moral quality of the Father and Son because it is associated with $\zeta \omega \eta$ and contrasted with the immoral darkness that characterises the world (see the section 'A moral narrative world'). The divine life-giving light shines on people to dispel their immoral darkness (1:9; 12:46; 1 Jn 2:8). Believers are called 'children of the light' when they accept the Light (12:35-36) and their subsequent behaviour should reflect the moral realm of light (3:19-21; 11:9-10; 1 Jn 1:7; 2:10).

\section{Love}

This value is articulated by the interchangeable nouns $\dot{\alpha} \gamma \alpha \dot{\pi} \pi \eta$

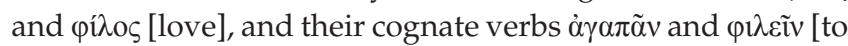
love]. Love is an identity marker in that it defines God (1 Jn 4:8, 16) and Jesus (in 17:26 God's love in the believer is equated to Jesus residing in the believer). The mutual love between the Father and the Son $(3: 35 ; 5: 20 ; 14: 31)$ is shared with or extended to the believer $(14: 21,23 ; 16: 27)$. Hence love identifies those who belong to God's family (13:34-35; 14:23; 15:12, 17; 1 Jn 2:9-11; cf. 8:42). ${ }^{8}$ God expressed his love for 6.For a study of John's $\zeta(\omega \eta$-ethic, see Stare (2012).

7.The Samaritan woman evidently has drunk from the life-giving water that Jesus offered her, and in turn she becomes a source of life-giving water for her fellow people in the village $(4: 28-30,39)$.

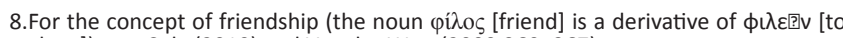
love]), see Culy (2010) and Van der Watt (2000:360-367). people by giving up his Son at the cross as an atoning sacrifice (i入 $\alpha \sigma \mu$ ó $)$ for humanity's sins (3:16; 1 Jn 4:8-10). Love drives Jesus to give his life for the life of the world (1 Jn 3:16). Hence love is a moral category because it compels God to act morally on behalf of immoral people. Similarly, the love that characterises believers should be tangible in their behaviour (13:34-35; 1 Jn 3:18).

\section{Truth}

This value is expressed by the noun $\dot{\alpha} \lambda \dot{\eta} \theta \varepsilon 1 \alpha$ [truth] and its cognate adjectives $\dot{\alpha} \lambda \eta \theta \hat{\prime} s$ and $\dot{\alpha} \lambda \eta \theta$ vvó $\varsigma$ [true]. 'Truth' is Johannine shorthand for the divine reality, i.e. the reality about God and the world above (cf. 1:9, 17; 3:33; 8:26, 40; 17:17). Like the other values, truth defines the Father (3:33; 17:3) and Son (14:6; 1 Jn 5:20). Jesus embodies and defines truth $(1: 14 ; 14: 6)$ but also mediates this truth to people $(1: 17-18 ; 3: 31-33 ; 8: 31-32,40,45$; cf. $6: 32,55)$. Truth is the defining moral component of Jesus' teaching because it liberates a person from sin and provides moral cleansing $(8: 31-32 ; 17: 17)$. Those who accept the truth are then 'from

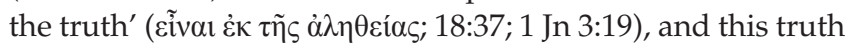
must shape believers' moral behaviour. Indeed John uses various expressions to stress that truth should be a demonstrable moral quality: 'to do the truth' (3:21), 'to testify to the truth' $(15: 27 ; 19: 35 ; 21: 24)$, 'to love in truth' (1 Jn 3:18; $5: 20)$, 'to worship in truth' (4:23-24), 'to be guided into the truth' (16:13), and 'to walk in the truth' (2 Jn 4; 3 Jn 3-4). ${ }^{9}$

In conclusion, the moral values that characterise the Father and Son and direct their actions, also determine the believer's character and conduct. In the following sections, it will be argued that believers can only live out these moral values to the extent that these have shaped their character and thinking. While John may not be as explicit as Paul in Romans 12:2, moral transformation relates to both a renewal of the mind and a corresponding change in behaviour. In turn, consistent moral behaviour strengthens and affirms moral thinking and character.

\section{Moral reasoning}

Believers or members of God's family are expected to align their thinking to their new environment, the world above, and this new thinking should inform their behaviour. ${ }^{10}$ To think 'from above' is to think in line with God's character and purposes; to reason according to the beliefs, values and norms of the world above. While John does not mention this concept explicitly, there are numerous implicit references.

Typically, characters in the Johannine narrative show thinking 'from below'. This is unsurprising considering people are 'from below' (cf. 8:23, 43-47). On various occasions Jesus starts a conversation at an earthly level but quickly moves to a spiritual level, and people are often unable to follow. Nicodemus, for example, misunderstands the spiritual birth

9.Van der Watt (2011:439) notes that while $\alpha \lambda \eta j \theta \varepsilon 1 \alpha$ in Greek philosophy refers more to existential reality, $\dot{\alpha} \lambda \dot{\eta} \theta \varepsilon ı \alpha$ with a verb of action is a Semitism.

10.Cf. Van der Watt (2012:190) who states that 'becoming part of the family of God changes a person's perspective' and thus the nature of his actions. 
'from above' and is unable to switch to a thinking 'from above' (3:1-12). The crowd sometimes responds well but all too often fails to understand Jesus (e.g. 6:25-34; 7:25-30; $12: 13,37-40)$. 'The Jews' are the ones who most frequently misunderstand (even refuse to understand) Jesus throughout John 5-12. Though Pilate is sympathetic to Jesus, he does not understand this king 'from above' (18:36-38; 19:9-11).

A few characters, however, do begin to think 'from above', although they struggle and often require Jesus' help. Initially the Samaritan woman misunderstands the nature of the living water (4:10-15), but starts to think 'from above' when Jesus changes tactics (4:16-26). Her cognitive progress sees her rushing back to the village and telling her people that, perhaps she has met the Messiah - and their response is overwhelming $(4: 28-30,39)$. It is reasonable to assume that she has drunk from the living water that Jesus offered her (Bennema 2002:189-192). The moral transformation of the Samaritan woman begins with thinking 'from above', followed by drinking of the 'living water', and then showing new behaviour in line with the new reality she has entered. In John 9 the man born blind shows a similar ability to think in categories 'from above', followed by the appropriate moral behaviour of believing and worshipping Jesus (9:38). Interestingly, the man's moral transformation becomes apparent not in a reflective encounter with Jesus (as was the case with the Samaritan woman) but during a biased and vicious confrontation with the hostile religious authorities.

When one looks at the Twelve, Jesus' closest disciples, it appears that during Jesus' ministry, they sometimes understand aspects of Jesus and his mission (e.g. 1:41, 45, 49; $6: 68-69 ; 16: 30 ; 17: 7-8)$, but mostly they do not. For example when Jesus goes from speaking of physical to figurative food in 4:31-34 in order to invite particular behaviour (to participate in his mission of 'reaping' people) the disciples are unable to follow. In stark contrast, the Samaritan woman drew her entire village to Jesus (4:30). In 6:5-9, Jesus tests Philip's ability to think 'from above' but he fails. In 11:11-14, the disciples do not understand when Jesus talks about Lazarus' 'sleeping' and 'awakening'. Even when Jesus provides extended private instruction, the disciples struggle to think 'from above' (13:6-10, 36-38; 14:5-9, 22; 16:16-18). At Jesus' arrest it becomes clear that Peter has not understood the nature of Jesus' mission (18:10-11). Even after the crucifixion, the misunderstanding continues: Peter, and perhaps even the Beloved Disciple, do not perceive the significance of the empty tomb (20:2, 8-10).

The teaching of the Johannine Jesus is enigmatic or ambiguous because it contains literary devices such as double entendre, metaphors, symbolism and irony, which are open to misunderstanding. In 16:25a Jesus refers to his teaching as

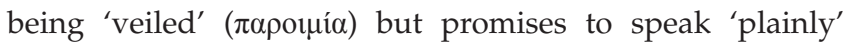
( $\pi \alpha \rho \rho \eta \sigma i \alpha)$ in the future (16:25b), referring to the time of the coming of the Spirit. According to 14:26 and 16:12-15, the Spirit will explain everything that Jesus has said in such a way that his words become plain. In 16:26-29 the disciples get a glimpse of that coming reality. Hence, while Jesus presents God's life-giving revelation, he does so in a 'veiled' way and the Spirit has the task of revealing its meaning and significance. John records a few instances where the disciples are able to grasp Jesus' teaching after the resurrection $(2: 17,22 ; 12: 26 ; 16: 4)$ and this thinking 'from above' is most likely the result of the Spirit's anamnesis. Indeed, in his first letter John describes the post-Easter reality where believers are able to think 'from above' because of the Spirit (1 Jn 2:27). The extent to which John and his fellow believers are now able to think 'from above', that is in terms of the beliefs, values and norms of God and his world, is indicated by the frequent phrase '(by this) we/you know that' (1 Jn 2:5, 18, 21; $3: 5,14-16,19,24 ; 4: 2,6,13 ; 5: 2,15,18-20)$. Indeed, in the postEaster era the cognitive darkness that tarnishes the world and its people $(1: 5,9-11)$ is dissipating (1 Jn 2:8).

In sum, Jesus taught in 'veiled' language and was often misunderstood because people failed to think 'from above', a prerequisite for gaining spiritual insight into the things of God. This means that Jesus' teaching must be 'unveiled' in order to be understood. In the post-Easter period the Spirit functions as a decoder, decrypting or unlocking Jesus' revelation, thereby enabling a thinking 'from above' and a corresponding moral behaviour. ${ }^{11}$ Moral reasoning or thinking 'from above' facilitates moral transformation because it informs and shapes both thought and behaviour according to the beliefs, values and norms of the world above. ${ }^{12}$ This moral shaping of character and conduct will be the topic of the next section.

\section{Moral behaviour and character}

Becoming part of God's family does not only result in a new identity but also a new mode of conduct, corresponding to the divine family ethos. As believers exist in the divine realm, they are instructed on how to behave morally in line with its beliefs, values and norms. This developing moral behaviour is usually referred to as 'discipleship'. Though discipleship in terms of coming to Jesus and remaining with him in order to have life is a soteriological category, it also has an ethical dimension that indicates the kind of conduct and character Jesus expects of his followers. Consequently we find various ethical imperatives in the Johannine writings to direct the believer's behaviour, such as to love one another, to abide in Jesus and his word, to bear fruit, to keep his commandments, to serve one another, to lay down one's life for others, to testify to Jesus, to 'do' or walk in the truth, to be pure and to be righteous. ${ }^{13}$ In the section 'Moral values' above, we saw

11. Whereas for John virtuous behaviour is rooted in Jesus' teaching, in early Judaism (e.g., 4 Macc, The Wisdom of Solomon, Philo) the law was the guide to virtuous behaviour. Thus while Hellenistic Judaism promotes a Torah-based identity and ethos, the Johannine (and other early Christian) literature advocates a Christ-based identity and ethos. Cf. Loader (2012); Tobin (2013:148-159); see also Van der Watt (2006b:152-157), who holds that a law-based Jewish value system is the foundation for Johannine ethics, albeit the law interpreted by Jesus.

12.Cf. Grönum (2015) who argues that fostering moral deliberation is important fo behavioural change, otherwise one only operates by instinctive behaviour guided by cultural schemata.

13.Zimmermann (2009) shows that moral instructions in the Johannine writings are not limited to grammatical imperatives, but can also be conveyed by other linguistic forms and ideas. 
that the divine moral qualities of life, light, love and truth do not simply constitute the believers' identity but also drive their behaviour. In fact, the Johannine writings stress the correlation between identity and behaviour. Hence moral transformation is broader than behaviour and also relates to identity.

John 8:39-47 shows the dynamics of identity and behaviour, and brings into sharp focus two mutually exclusive families. When 'the Jews', seeking to clarify their identity, claim that Abraham is their father, Jesus says that if this were the case they would demonstrate corresponding behaviour (8:39). The 'if you were ... you would $d o^{\prime}$ construction (it is repeated in 8:42) illustrates that identity demands matching behaviour and conversely that behaviour reveals identity. As it is, the conduct of 'the Jews' does not resemble Abraham's but that of a different father (8:40-41). Their behaviour shows that they belong to the devil's family - they share the devil's identity and their behaviour is influenced by him (8:44). Indeed the conduct of 'the Jews' is consistent with this identity - they $\sin (8: 24)$, lie $(8: 33,55)$, seek to kill Jesus $(8: 37,40,59)$, are averse to the truth and do not understand the words of Jesus or God $(8: 43,45,47)$, insult Jesus (8:48) and dishonour him (8:49) (cf. Van der Watt 2006a:423-436). ${ }^{14}$ Thus identity informs and demands corresponding behaviour, and conversely, behaviour reveals and validates identity.

This correlation between identity and behaviour is highlighted throughout John's Gospel. To his followers, Jesus stresses that keeping his commandments shows their love for him $(14: 15,21,23)$ and guarantees his abiding love (15:10). Similarly their loving one another is a testimony to their identity as Jesus' disciples (13:35). Elsewhere Jesus asserts that abiding in him, that is being in relationship with him (identity), warrants that they bear fruit (behaviour) (15:4-5), and in turn their bearing fruit will reveal identity (15:8). ${ }^{15}$ To 'the Jews' who had believed, Jesus says that if they continue to adhere to his teaching (behaviour), they would prove themselves to be his disciples (identity) (8:31) - but sadly they do not, as the rest of the chapter shows.

1 John is also replete with examples of this correlation between identity and behaviour. I will mention a few:

- anyone claiming to have communion with God (identity) must show matching behaviour; conversely one who 'walks' in the light or darkness (behaviour) is in the light or darkness (identity) (1 Jn 1:6-7; 2:9-11);

- keeping God's commandments (obedient behaviour) affirms one's communion with God (one knows God and is 'in him') and one's share in the divine attributes of truth and love (identity) (1 Jn 2:3-6);

- identity and behaviour are inseparable in either family to do right (to do no sin) is to be right, to be of God; to commit sin is to be of the devil (1 Jn 3:7-10);

14.Van der Watt $(2000: 192,199-200)$ also notes the contrasting origins - "the Jews are ?k the world or devil $(8: 23,44)$ while Jesus and believers are ?k above or God $(8: 23,42,47)$. People's origin determines group affiliation and consequently their actions within that group. Thus a child acts according to his or her identity, which is established at birth.

15. Гíve $\sigma \theta \alpha$ denotes 'to be' rather than 'to become' in 15:8.
- when God's love abides in the believer (identity), it must result in corresponding behaviour (1 Jn 3:17), just as to 'love in truth' (behaviour) demonstrates that one is of the truth (identity) (1 Jn 3:18-19);

- to love (behaviour) is to be (born) of God who is love, and guarantees one's communion with him (identity) (1 Jn 4:7-8, 12);

- to testify (behaviour) shows communion with God (identity) (1 Jn 4:15);

- love (identity) is inextricably linked with, even defined by, obedience (behaviour) (1 Jn 5:2-3). ${ }^{16}$

A picture emerges that believers' inclusion in the divine identity must precipitate transformational behaviour in that they are expected to behave according to the divine family code. Believers (should) behave like children of God because that is who they are. The believer's ongoing access to the divine reality results in a growing awareness of who God is, what he does and what he expects from people. This moral knowledge should motivate a believer to do what is right. At the same time, behaviour is transformative - right behaviour affirms and shapes one's identity. Continuous acts of discipleship (behaviour), such as believing, loving, following, abiding, obedience, serving and testifying, authenticate and shape the family bond between the believer, God and fellowbelievers (identity). Thus there is a reciprocal, transformative dynamic between identity and behaviour; each has the potential to shape the other.

\section{Characters as moral agents}

Any meaningful communication, verbal or written, has a particular message that the speaker or author wants to convey to the audience. In line with its purpose, a story is told or written from a particular perspective, called 'point of view'. John's point of view is informed by his purpose for writing and his worldview. The soteriological-moral purpose of John's writings is to evoke and strengthen life-giving belief in Jesus among his readers (20:31; 1 Jn 5:13). Likewise the Johannine worldview is characterised by a soteriological-moral dualism (see the section 'A moral narrative world'). John communicates his moral perspective or point of view through the characters in the story, subtly leading the reader to evaluate the characters and creating affinity with or distance from these characters (Pennington 2012:162-163; Rhoads, Dewey \& Michie 2012:102). Consequently the narrative is not neutral because it has an inbuilt perspective that is communicated to the readers, and they must evaluate the characters against the author's evaluative point of view (Bennema 2014a:48-49, 90-96).

This means that the characters are potential change agents they have the ability to effect transformation in the reader. An examination of Johannine characters as agents of moral transformation will inform the discipline of virtue ethics. ${ }^{17}$

16.Frey (2013:174-177) argues that in reflecting an ethos of separation from pagan cults or the Gentile world, 1 John adopts essentially a Diaspora Jewish ethos.

17. Bennema (2013) uses an Aristotelian lens to explore how the Johannine characters act as moral agents regarding the cardinal virtues of prudence, courage, justice and temperance. For a broader discussion of character ethics, see Hauerwas (1972) and also Wagener (2015). 
We mentioned virtue ethics in the section 'A moral narrative world' above, but I wish to return to it here. Virtue ethics is a form of normative ethics that describes the character of a moral agent as a driving force for ethical behaviour rather than duty to rules (deontology), consequentialism (deriving rightness or wrongness from the outcome of the act itself), or social context (pragmatic ethics). So, in order to model and promote moral thinking and behaviour among his audience, John presents various characters as models that can influence change in the reader. While some characters exemplify characteristics and behaviour that the reader might emulate, other characters display traits or behaviour that should be avoided.

Many Johannine characters are unable to think 'from above' (e.g. Nicodemus, 'the Jews', the invalid at the pool, Philip in 6:5-7, the crowd, Peter in 13:36-38 and 18:10-11, Pilate; cf. the section 'Moral reasoning' above). Other characters, however, manage to do so, albeit with Jesus' help (the Samaritan woman, Peter in 6:68-69, the blind man in 9:17-38, Martha in 11:21-27, Mary Magdalene in 21:14-18, Thomas in 21:25-28), and they function as models of moral reasoning. In terms of behaviour 'the Jews', Judas and Pilate, for example, are immoral characters. 'The Jews' choose ( $\theta \dot{\varepsilon} \lambda \varepsilon ı v)$ to emulate their father, the devil; in other words, their behaviour results from their identity and is volitional (8:44). Pilate knows the truth (Jesus is innocent) but does not act on it. Judas is characterised by dishonesty and disloyalty; as a thief and traitor, he betrays the trust of the group. While Peter is mercurial during Jesus' ministry, we learn that he will be a reliable and virtuous character later (21:15-19; cf. 1 Pet. 5:1-3). The Samaritan woman is a virtuous character and a model of moral transformation in that she gradually sees something true about Jesus' identity and acts in line with his mission. Characters are virtuous to the extent that their thinking and behaviour corresponds to the beliefs, values and norms of God's world. ${ }^{18}$

In conclusion, the believers' moral transformation relates to the extent that they think and behave 'from above'. John models and promotes such morality by presenting various characters in his narrative that his readers should evaluate according to his point of view. ${ }^{19}$ Although we did not elaborate, the personal example of Jesus is of course most influential for

18.Philo's virtue ethics is influenced by the four cardinal virtues in Stoicism and the biblical virtues. Using allegorical exegesis, Philo presents various biblical characters as symbols of virtues. Philo also elucidates the moral progress of biblical characters (with Abraham as the archetypal figure) towards becoming like God (homoiousios) in a Abraham as the archetypal figure) towards becoming like God (homoiousios) in a
face-to-face encounter with God (Bennema 2002:74-82; Lévy 2009:150-154, 164-167). face-to-face encounter with God (Bennema 2002:74-82; Lévy 2009:150-154, 164-167). Graeco-Roman virtue ethics also has a cognitive component. For Aristotle Evidalpovio is 'an activity of the soul', which refers to human rational activity and comes as a result of virtue (]pErń) and education (NE I.7, 9). Aristotle distinguishes between intellectua virtues and moral virtues (NE I.13). The cardinal virtues include the moral virtues of courage, temperance and justice, and the intellectual virtue of prudence. As MacIntyre (1981:144-145) explains, prudence is that intellectual virtue without which none of the moral virtues can be exercised, and conversely, prudence requires the presence of the moral virtues. As in John, right thinking and right behaviour are inextricably linked in Graeco-Roman ethics (cf. Pakaluk 2005:206-232)

19.While most (but not all) Graeco-Roman characters are consistent ethical types, many Johannine characters are more 'round', showing various degrees of complexity and development (Bennema 2014b:349-350). Besides, while the audience of a Greek drama evaluates the protagonist as a model to be emulated or avoided and the minor characters are an aid to the protagonist's characterisation, readers of the Johannine narrative are invited to evaluate the minor characters, who exist for the benefit of the reader (Bennema 2016b:367). In contrast, Brant (2004:159-166) contends that the Johannine characters, like the characters of an ancient Greek tragedy, should not be held accountable or be evaluated because ancient Greek tragedy, should not be hel
their actions are determined by the plot. moral transformation because Jesus often sets the example for appropriate moral behaviour that he expects his disciples (and later believers) to follow (e.g., 12:26; 13:15, 34; 15:10; 17:21-22; 20:21; 1 Jn 2:6; 3:16; see also Bennema 2016a).

\section{Conclusion}

In this article I explored the Johannine idea of moral transformation. This study has shown that the Johannine writings present a moral God saving immoral people by bringing them through a new birth into his moral world where they will experience moral transformation. For John the single moral 'work' that God requires from humans is to believe in Jesus. Such belief results in people participating or sharing in the divine life, the ultimate moral good people can attain. Thus, within John's dualistic scheme, the believer is transferred from the world below to the world above characterised by moral commodities such as life, light, love and truth. Being part of this new reality with access to various moral goods, results in the believer's moral transformation. Believers will be transformed to the extent that they practise moral reasoning and behave in accordance to the beliefs, values and norms of God's world. John models and promotes the envisaged morality to his readers by presenting various characters, whose characteristics and behaviour might be emulated or should be avoided.

Soteriology and ethics are intrinsically related in the Johannine writings in that John presents salvation as people's entry into a life-giving relationship with God where moral transformation takes place. Patterned after the character and behaviour of the Father and Son, believers are shaped in their identity and behaviour. Thus, God's family is the locus of moral transformation and believers are brought into this relational realm through the Spirit. ${ }^{20}$ The believer's participation in the divine relationship is dynamic and sharing in this divine identity is profoundly transformative, affecting one's being, thinking and doing. ${ }^{21}$ The correlation between a believer's identity and behaviour is that identity informs and shapes behaviour, and conversely, behaviour reveals and affirms identity.

This article opens up further lines of enquiry. Firstly, the believers' inclusion or participation in the divine identity and life may relate to the concept of theosis. It could be argued, for example, that the believer's ongoing moral transformation can be understood as theosis in terms of participation in God's life and character in order to become like God (homoiousios) rather than participation in God's essence in order to become God (homoousios). ${ }^{22}$ Secondly, moral reasoning and behaviour is rooted in Jesus' teaching and personal example. At the end of the section 'Characters as moral agents', we noted that Jesus models appropriate moral behaviour in that he often indicates that the behaviour of his followers should be patterned on his

20. Contra Buch-Hansen (2010), who presents a Stoic reading of John to argue that the believer's (ontological) transformation is caused by an infusion of (material) $\pi v \varepsilon$ ? $\mu \alpha$.

21.Van der Watt (2011:443) thus rightly identifies Johannine ethics as relational ethics. For the idea that intimate, loving relationships enable the believers' ethical life, see Rabens (2012).

22.For a similar discussion of theosis in Paul, see Rabens (2016). 
own. Mimesis is a pervasive concept in the Johannine writings that has largely gone unnoticed in scholarship (but see Bennema 2016a), and if the goal of mimesis is for the imitator to become like the one who sets the example, mimesis could be instrumental for moral transformation.

\section{Acknowledgements Competing interests}

The author declares that he has no financial or personal relationships which may have inappropriately influenced him in writing this article.

\section{References}

Bennema, C., 2002, The power of saving wisdom: An investigation of spirit and wisdom in relation to the soteriology of the fourth Gospel, Mohr Siebeck, Tübingen.

Bennema, C., 2013, 'Virtue ethics in the Gospel of John: The Johannine characters as moral agents', in L.D. Chrupcała (ed.), Rediscovering John: Essays on the fourth Gospel in honour of Frédéric Manns, pp. 167-181, Terra Santa, Milan.

Bennema, C., 2014a, A theory of character in New Testament narrative, Fortress, Minneapolis.

Bennema, C., 2014b, Encountering Jesus: Character studies in the Gospel of John, 2nd edn., Fortress, Minneapolis.

Bennema, C., 2016a, 'Mimetic ethics in the Gospel of John', in U. Volp, F.W. Horn \& R. Zimmermann (eds.), Metapher-narratio-mimesis-doxologie, pp. 205-217, Mohr Siebeck, Tübingen.

Bennema, C., 2016b, 'Character reconstruction in the New Testament, pt. 1: The theory', Expository Times 127, 365-374.

Bolyki, J., 2003, 'Ethics in the Gospel of John', Communio Viatorum 45, 198-208.

Brant, J.-A., 2004, Dialogue and drama: Elements of Greek tragedy in the fourth Gospel, Hendrickson, Peabody.

Buch-Hansen, G., 2010, 'It is the spirit that gives life': A stoic understanding of pneume in John's Gospel, De Gruyter, Berlin.

Culy, M.M., 2010, Echoes of friendship in the Gospel of John, Phoenix, Sheffield.

Frey, J., 2013, “Ethical" traditions, family ethos, and love in the Johannine literature', in J.W. van Henten \& J. Verheyden (eds.), Early Christian ethics in interaction with Jewish and Greco-Roman contexts, pp. 167-203, Brill, Leiden.

Grindheim, S., 2016, 'The work of God or of human beings: A note on John 6:29', Journal of the Evangelical Theological Society 59, 63-66.

Grönum, N.J., 2015, 'A return to virtue Ethics: Virtue ethics, cognitive science and character education', Verbum et Ecclesia 36.1, http://dx.doi.org/10.4102/ve. v36i1.1413
Hauerwas, S., 1972, 'Towards an ethics of character', Theological Studies 33, 698-715. Lévy, C., 2009, 'Philo's ethics', in A. Kamesar (ed.), The Cambridge companion to Philo, pp. 146-171, Cambridge University Press, Cambridge.

Lincoln, A.T., 2005, The Gospel according to Saint John, Continuum, London.

Loader, W.R.G., 2012, 'The law and ethics in John's Gospel', in J.G. van der Watt \& R. Zimmermann (eds.), Rethinking the ethics of John, pp. 143-158, Mohr Siebeck, Tübingen.

Maclntyre, A., 1981, After virtue: A study in moral theory, Duckworth, London.

Pakaluk, M., 2005, Aristotle's Nicomachean ethics: An introduction, Cambridge University Press, Cambridge.

Pennington, J.P., 2012, Reading the gospels wisely, Baker Academic, Grand Rapids.

Rabens, V., 2012, 'Johannine perspectives on ethical enabling in the context of stoic and philonic ethics', in J.G. van der Watt \& R. Zimmermann (eds.), Rethinking the ethics of John, pp. 114-139, Mohr Siebeck, Tübingen.

Rabens, V., 2016, 'The Holy Spirit and deification in Paul: A “western" perspective', in P. Dragutinovic, K.-W. Niebuhr \& J.B. Wallace (eds.), The Holy Spirit and the church according to the New Testament, pp. 187-220, Mohr Siebeck, Tübingen.

Rhoads, D.M., Dewey, J., \& Michie, D., 2012, Mark as story, 3rd edn., Fortress, Philadelphia.

Stare, M., 2012, 'Ethics of life in the Gospel of John', in J.G. van der Watt \& R. Zimmermann (eds.), Rethinking the ethics of John, pp. 213-228, Mohr Siebeck, Tübingen.

Tobin, T.H., 2013, 'The importance of Hellenistic Judaism for the study of Paul's ethics', in J.W. van Henten \& J. Verheyden (eds.), Early Christian ethics in interaction with Jewish and Greco-Roman contexts, pp. 147-165, Brill, Leiden.

Van der Watt, J.G., 1999, 'Ethics in first John: A literary and socioscientific perspective', Catholic Biblical Quarterly 61, 491-511.

Van der Watt, J.G., 2000, Family of the King: Dynamics of metaphor in the Gospel according to John, Brill, Leiden.

Van der Watt, J.G., 2006a, 'Ethics alive in imagery', in J. Frey, J.G. van der Watt \& R. Zimmermann (eds.), Imagery in the Gospel of John, pp. 421-448, Mohr Siebeck, Tübingen.

Van der Watt, J.G., 2006b, 'Ethics and ethos in the Gospel according to John', Zeitschrift für die Neutestamentliche Wissenschaft 97, 147-176.

Van der Watt, J.G., 2011, 'The Gospel of John's perception of ethical behaviour', In die Skriflig 45, 431-447.

Van der Watt, J.G., 2012, 'Ethics of/and the opponents of Jesus in John's Gospel', in J.G. van der Watt \& R. Zimmermann (eds.), Rethinking the ethics of John, pp. 175-191, Mohr Siebeck, Tübingen.

Van der Watt, J.G. \& Zimmermann, R. (eds.), 2012, Rethinking the ethics of John, Mohr Siebeck, Tübingen.

Wagener, F., 2015, Figuren als Handlungsmodelle: Simon Petrus, die samaritische Frau, Judas und Thomas als Zugänge zu einer narrativen Ethik des Johannesevangeliums, Mohr Siebeck, Tübingen.

Zimmermann, R., 2009, 'The "implicit ethics" of New Testament writings: A draft on a New methodology for analysing New Testament ethics', Neotestamentica 43 , 399-423. 